\title{
Incidence of Contextual Variables on School Mathematical Achievement
}

\author{
Ramón García-Perales ${ }^{1 *}$, Ascensión Palomares-Ruiz ${ }^{2}$ \\ ${ }^{1}$ University of Castilla-La Mancha (UCLM), SPAIN \\ *CORRESPONDENCE: $\square$ Ramon.GarciaPerales@uclm.es
}

\begin{abstract}
The study of math achievement is fundamental. Its importance lies in analyzing what variables affect a significant percentage of students is not to reach their basic standards. In this sense, the contextual variables may become decisive. The purpose is to analyze data obtained after administration to a sample of students of an evaluation tool that measures mathematical competence. The data were analyzed from two contextual variables, ownership and environment centres, demonstrating statistically significant differences. The evaluation of the students should develop in all its scope, adequately considering the competences and the contextual elements that may influence their results.

Keywords: competences, math achievement, mathematics education, private and public education, rural and urban education
\end{abstract}

\section{INTRODUCTION}

The educational intervention must be based on a multidirectional, participatory and creative methodological that facilitates schoolchildren's full and integral development, independently of their personal and contextual characteristics. Therefore, to achieve an inclusive and quality education for all students, competence-based education is born as a clear commitment in educational matters of various national and international organizations. In this line, starting from the distinctive notes of the current knowledge society, international institutions such as the Organization for Economic Cooperation and Development (OECD) and the European Union (EU) intend that all students, whatever their abilities and their needs, achieve a sufficient level of competence to function autonomously and effectively in their social environment. Among these skills to be developed by students, are mathematics. The transcendence of this area is obvious and its generalization to everyday life justifies the learning of its elements, algorithms and logic. This social vision justifies the realization of this research from an educational perspective. Centers, whatever their type and teachers must create real opportunities for their learning and develop classroom process indicators capable of showing what is done in the centers and classrooms, whether public or private, rural or urban. It is necessary to analyze what learning opportunities they offer and see if, using mathematical competence, there are statistically significant differences between them (Cleary \& Chen, 2009; Guven \& Cabakcor, 2013).

\section{CONCEPTUAL REFERENTS}

The learning by competences is defined as an educational current that aims to demonstrate what has been learned in real life contexts, where the student is the protagonist of his learning, permanently to achieve its

Article History: Received 31 October $2019 \bullet$ Revised 25 November $2019 \bullet$ Accepted 26 November 2019

(C) 2020 by the authors; licensee Modestum Ltd., UK. Open Access terms of the Creative Commons Attribution 4.0 International License (http://creativecommons.org/licenses/by/4.0/) apply. The license permits unrestricted use, distribution, and reproduction in any medium, on the condition that users give exact credit to the original author(s) and the source, provide a link to the Creative Commons license, and indicate if they made any changes. 
integral development (López, 2013). Their integration in the educational practices entails important changes, as much in the curricular, methodological and organizational elements, like in the forms of participation of the whole of the educative community. This integration of work by competences coexists with social, cultural and educational challenges existing in today's society, such as the training of citizens who participate and develop autonomously in community, or the consolidation of an egalitarian and diverse school with a marked inclusive character that respond to diversity. In this way, the incorporation of the competences to the work dynamics of the schools will make it possible to respond to the needs of their social and cultural environment, enabling the students to face the demands that each situation requires of them in real stages.

Due to the complexity of carrying out the evaluation processes by competences, from the educational centers different procedures and instruments are used in a complementary way, not being focused only on terminal tests at the end of each didactic unit. Therefore, the generalization of specific research and materials that bring the teacher closer to the development of evaluative processes by competences is a fundamental task in order to unite theoretical reflection with school practice.

An example of evaluation by competences has been the Program for International Student Assessment (PISA), a program that has achieved great importance due to the high number of participating centers and countries, 18,541 centers and 535,791 students in the 2015 edition (Ministry of Education, Culture and Sports -MECD-, 2016a), the concretion of their theoretical frameworks and the exhaustiveness of the developed analyzes, allowing the comparison between countries each to generate effective and quality educational policies. PISA has been cataloged by several authors as a Rorscharch Test where governments distinguished their preconceived ideas (Meyer \& Benavot, 2013). However, we must recognize that it has become an instrument that brings us closer to educational realities, contributing with quantitative data based on numerous variables that allow large-scale comparison.

All this demands a respect and rigor with the many sociological and historical peculiarities that shape the education of each country, so justifying any reform in the PISA results would imply directing education to the interests of the ideological front of neoliberalism (Fernández-González, 2015). The objectives of PISA are: assess competences, detect influential factors in academic performance such as attitudes and learning styles, draw conclusions that facilitate the generalization of educational policies and, finally, consider the results obtained according to socio-economic variables of a family nature and school, such as the ownership and geographical environment of educational centers.

With these variables in mind, one of the PISA analyzes is the connection between equity and performance. Equity is considered as an essential element and purpose of any educational system. An educational system is equitable when it reduces the social and economic inequalities existing in the population to impact the performance of personal effort and capabilities (Sicilia \& Simancas, 2018; Torres \& Castillo, 2016). In the words of Arnaiz (2012, p. 25), "the 21st century school must promote a democratic and inclusive education that guarantees the principles of equality, equity and social justice for all students". The inclusion of the study of equity in research is justified by the generalization of conclusions and proposals for educational action according to characteristics and specific circumstances of the students themselves and their resources for learning, their families, their school and their environment.

Therefore, the lower the impact of these factors on the performance of students in assessment tests, the greater equity will be considered to have the education system of a country. Factors such as the personal potential of the individual and the characteristics of their family, social and cultural environment, have a decisive influence on the educational performance that a subject can achieve (Calero, Quiroga, Escardíbul, Waisgrais, \& Mediavilla, 2008; Choi \& Calero, 2013; Guven \& Cabakcor, 2013; OECD, 2016, 2019).

Lassibille and Navarro (2004) point out that in order to measure the educational individuals performances, we must bear in mind the relationship between five categories of variables, constituting as one of them the sociocultural context in which educational work is integrated. Within this category are included both variables related to the family and the school, noting among the latter the two central contextual variables of this article and which are then defined and analyzed, ownership and environment of the educational centers.

In relation to this issue, PISA 2012 highlights that to deepen the knowledge of how to operate an educational system is "essential to assess another essential aspect associated with its optimal functioning, the degree of equity that benefit its main users, students" (National Institute for Educational Evaluation -INEE, 2013, p. 86). In the 2015 edition, the last evaluation developed within this program of the OECD, among the conclusions regarding equity, it is stated that, "guaranteeing disadvantaged and difficult students access to high quality centers (...) can be a way to increase the socioeconomic and academic inclusion of the centers in 
Table 1. Centers and participating students according to the ownership of schools

\begin{tabular}{ccccc}
\hline & \multicolumn{2}{c}{ Schools } & \multicolumn{2}{c}{ Students } \\
\cline { 2 - 5 } & $\boldsymbol{n}$ & $\boldsymbol{\%}$ & $\boldsymbol{n}$ & $\boldsymbol{\%}$ \\
\hline Public & 20 & 83.33 & 592 & 83.14 \\
\hline Private & 4 & 16.67 & 120 & 16.85 \\
\hline Total & 24 & 100 & 712 & 100 \\
\hline
\end{tabular}

Source: Own elaboration, 2019

the future" (OECD, 2015b, p. 4) and, "the improvement of performance in PISA is not related to the geographical situation, national wealth or culture" (OECD, 2015a, p. 1), because, "over time, excellence and equity in education are not mutually exclusive objectives, as evidenced by the improvement observed in Germany, Italy, Mexico, Tunisia and Turkey" (OECD, 2015a, p. 1).

In Spain, in the developed PISA editions, it is observed that, in the education system there is a remarkable equity, there being a low variability of the results according to environmental conditions (INEE, 2010b, 2013; OECD, 2015a, 2015b, 2019), being more determining the individual aspects that the institutional characteristics of the centers (INEE, 2013). In addition, in the 2012 edition, it is stated that "better attention can be achieved, both for excellent students and for laggards, without being detrimental to equity" (INEE, 2013, p. 70). These conclusions regarding equity are in line with the results of Spain in the Trends in International Mathematics and Science Study (TIMSS) evaluation of 2011 and 2015, since Spain is one of the countries where the differences in performance between schools are more reduced (INEE, 2012, 2016).

\section{METHOD}

In this research, a descriptive quantitative methodology has been used to know, predict and study the relationships between a set of data. To develop this purpose, two contextual variables, ownership and environment of the educational centers have been used. The aim has been to assess to what extent these two variables affect the performance of students in the area of Mathematics. To do this, a battery of students has been administered the Mathematical Competency Assessment Battery (BECOMA).

The research has been developed with a representative sample of a spanish region, Castilla-La Mancha. This sample has been selected in a stratified and proportional manner according to the number of students enrolled in 5th year of Primary Education, students between 10 and 12 years old, and based on the variables established as social strata, in this case ownership (public or private) and environment (rural or urban) of the schools. In this way, the participating sample has been 712 students or $17.94 \%$ of the total subjects enrolled in this school level of this province (3.968 students).

In the research 24 centers have been selected, of which 20 are public and another 4 are private. In the selection of the sample according to this variable, the existing percentages have been followed at the provincial and regional levels, where public education accounts for $83 \%$ of the total number of centers and private education $17 \%$. The same percentages have been maintained with respect to the students, as shown in Table 1.

Regarding the variable environment, the students enrolled in schools with populations over 10,000 inhabitants have been considered as urban and the lower as the rural environment. This research has integrated the internal assessment of mathematical performance in the rural school intending to reduce, from the humility of the authors of this article, the empirical gap that exists over these centers as there is not enough educational research on them (Bustos, 2011).

In this province, there are 135 educational centers with the 5th grade of Primary Education. Of these, 82 centers are located in urban areas (60.74\%) and 53 in rural areas (39.26\%). The distribution of the sample was $69.8 \%$ for urban centers (497 students) and 30.2\% (215 students) for rural centers. As shown in Table 2, in this variable we have selected percentages close to those existing in the total of the province, $60.74 \%$ of urban versus $39.26 \%$ of rural. The number of participating students according to this variable has not been considered when selecting the sample because the figures of schooling among these centers are very different, the urban ones have had ratios between 15 and 30 students by class while the rural ones have between 1 and 30 students. 
Table 2. Centers and participating students according to the environment of the schools

\begin{tabular}{ccccc}
\hline & \multicolumn{2}{c}{ Schools } & \multicolumn{2}{c}{ Students } \\
\cline { 2 - 5 } & $\boldsymbol{n}$ & $\boldsymbol{\%}$ & $\boldsymbol{n}$ & $\mathbf{\%}$ \\
\hline Urban & 14 & 58.34 & 497 & 69.8 \\
\hline Rural & 10 & 41.66 & 215 & 30.2 \\
\hline Total & 24 & 100 & 712 & 100 \\
\hline
\end{tabular}

Source: Own elaboration, 2019

The main variable of the investigation has been mathematical competence. Its operative definition has been key to obtain high indexes of content validity (Castro, 2011), in this case, the average index has been .80, calculated after the realization of an expert judgment with 51 teachers with university degree in Mathematics. This competence is defined by PISA 2012, the last edition that takes this area as a priority of the evaluation, such as:

The individual's ability to formulate, use and interpret mathematics in different contexts. It includes mathematical reasoning and the use of concepts, procedures, data and mathematical tools to describe, explain and predict phenomena. It helps individuals to recognize the role that mathematics plays in the world and to issue judgments and well-founded decisions that constructive, committed and reflective citizens need (INEE, 2013, p. 12-13).

The instrument used, called BECOMA, has items that are closely related to the curricular base of the teaching and learning processes in the area of Mathematics and to the assessment indicators for mathematical competence used in international PISA performance evaluations. The battery consists of 34 items with a weight of 0,1 or 2, and the total score can range between 0 and 68, with an application time of 49 minutes. These items are divided between 8 evaluation tests and 6 factors: Successions (6 items), Graphic structuring (9 items), Parts of the whole (7 items), Problem solving (4 items), Ten-hundred-thousand (5 items) and Decomposition and properties (3 items). Some examples of items are: 


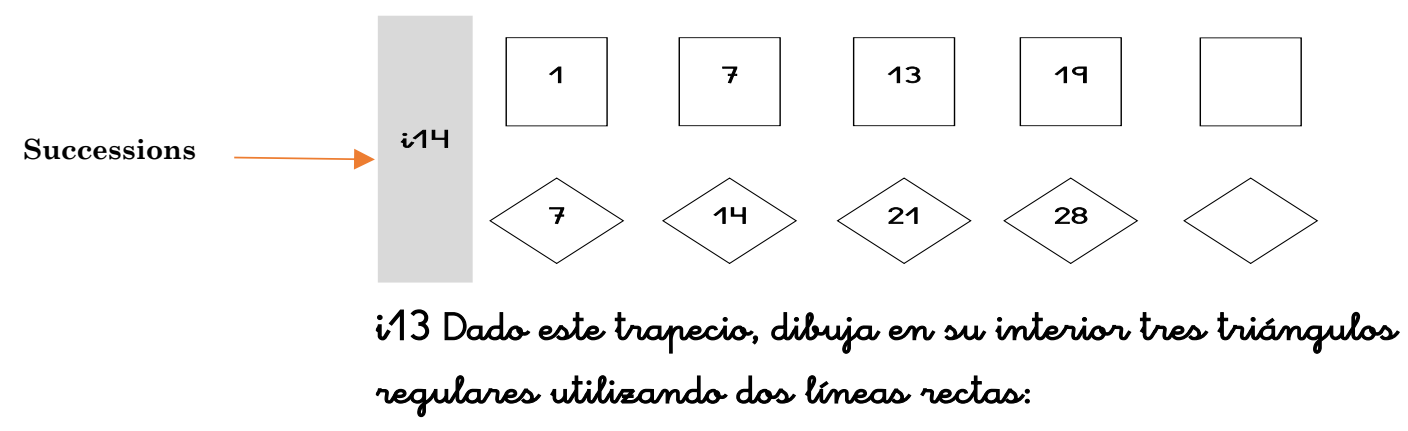

Graphic

structuring

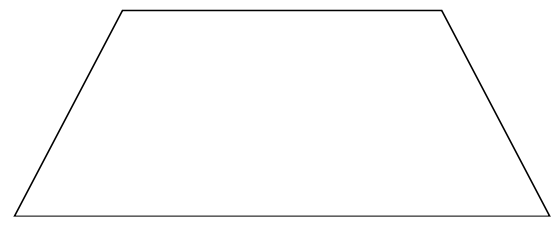

Parts of

i22 si 8 trabajadores ponen 100 metros de tuberia al dia en el alcantarillado del pueblo,

the whole

¿cuántos metros pondrán 16 trabajadores?

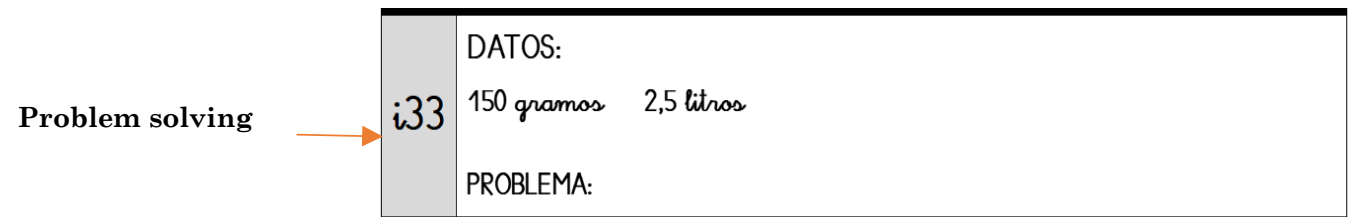

Ten-hundred-

thousand

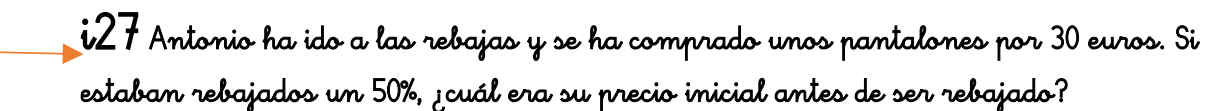

\begin{tabular}{l|l|l|l|}
\hline \multirow{3}{*}{$\begin{array}{l}\text { Decomposition and } \\
\text { properties }\end{array}$} & $28 \times 8=$ & \\
\cline { 2 - 3 } & $3 \times 49=$ & \\
\hline
\end{tabular}

Figure 1. Examples of BECOMA items

Finally, it has contacted the educational centers in which the students were enrolled to request their collaboration. The families of these students have been informed and have supported the viability of this research. The anonymity of the participants and their educational centers and the confidentiality of the results have been guaranteed. The statistical program SPSS has been used for the analysis of the results. The learning by competences is defined as an educational.

\section{RESULTS}

The results of the BECOMA battery have been distributed in 7 levels of mathematical performance: 1, 2, 3, 4, 5, 6 and 7. Level 1 represents the lowest degree domain and 7 is the highest level. These levels allow the description of what students know and can do for each of them. This way of proceeding is common in current research (Roderer and Roebers, 2013, OECD, 2009, 2012, 2016 and 2019). In this way, for the variables environment and ownership of the center, the following results appear for each level: 
Table 3. Perfomance levels and ownership and environment of educational centers

\begin{tabular}{|c|c|c|c|c|c|c|c|c|c|c|c|}
\hline \multirow{3}{*}{ Levels } & \multirow{3}{*}{ Intervals } & \multirow{3}{*}{$n$} & \multirow{3}{*}{$\%$} & \multicolumn{4}{|c|}{ Ownership } & \multicolumn{4}{|c|}{ Environment } \\
\hline & & & & \multicolumn{2}{|c|}{ Public } & \multicolumn{2}{|c|}{ Private } & \multicolumn{2}{|c|}{ Rural } & \multicolumn{2}{|c|}{ Urban } \\
\hline & & & & $n$ & $\%$ & $n$ & $\%$ & $n$ & $\%$ & $n$ & $\%$ \\
\hline 1 & $<=8$ & 14 & 2.0 & 12 & 1.69 & 2 & 0.28 & 4 & 0.56 & 10 & 1.40 \\
\hline 2 & $9-18$ & 88 & 12.4 & 72 & 10.11 & 16 & 2.25 & 32 & 4.49 & 56 & 7.87 \\
\hline 3 & $19-28$ & 165 & 23.2 & 135 & 18.96 & 30 & 4.21 & 50 & 7.02 & 115 & 16.15 \\
\hline 4 & $29-38$ & 184 & 25.8 & 158 & 22.19 & 26 & 3.65 & 57 & 8.01 & 127 & 17.84 \\
\hline 5 & $39-48$ & 159 & 22.3 & 131 & 18.40 & 28 & 3.93 & 50 & 7.02 & 109 & 15.31 \\
\hline 6 & $49-58$ & 80 & 11.2 & 64 & 8.99 & 16 & 2.25 & 18 & 2.53 & 62 & 8.71 \\
\hline \multirow[t]{2}{*}{7} & $59-68$ & 22 & 3.1 & 20 & 2.81 & 2 & 0.28 & 4 & 0.56 & 18 & 2.53 \\
\hline & Total & 712 & 100.0 & 592 & 83.15 & 120 & 16.85 & 215 & 30.20 & 497 & 69.80 \\
\hline
\end{tabular}

Source: Own elaboration, 2019

As can be seen, there are differences between centers according to their typology for each of the levels of mathematical performance. Next, an in-depth analysis of these differences is made, observing the performance of the students for each item and factor to verify that the differences are not due exclusively to the existing sample inequality according to the contextual variables used.

Regarding the ownership of the center, in PISA 2012 (edition that evaluates this competence in a preferential way), the sample of participating private centers in Spain was 31\%, a percentage well above the OECD average of $18 \%$ (MECD, 2016b). In this edition of PISA, in this country, average results were higher by 30 points in private centers compared to public ones, this difference was 27 points in the OECD average. Several studies indicate that these differences could be derived from the socioeconomic and cultural level of the families of their school students (INEE, 2010b and 2013; MECD, 2016b). Besides "although private centers tend to perform more than public ones, the differences between centers of different ownership would decrease considerably if the social, economic and cultural levels between public and private centers in Spain were similar" (INEE, 2013, p. 122).

The region in which this research is developed, Castilla La Mancha, at the time of the development of this study, the distribution of students enrolled according to this variable has been $82.3 \%$ in public schools and $17.7 \%$ in private schools. In the province of Albacete has been $83.75 \%$ in public education and $16.25 \%$ in private. In the development of this research, the distribution of students according to the ownership of the centers has been $83.1 \%$ for public (592 students) and $16.9 \%$ private (120 students).

BECOMA has been the battery used in the investigation, a pedagogical assessment instrument with highreliability indexes (Cronbach's Alpha between .73 and .90) and validity (content, construct and criterion, indexes between .80 and .90) after its design and construction.

The analysis of the results according to the ownership of the centers has not shown statistically significant differences between both types of schools for this variable (Table 4), except for some specific items in which there has been significant. In items 14, 21, 23 and 31 the significance has been in favor of the public and in 2 , 10 and 33 of the private. In relation to the averages reached by each type of center, the average value of public schools was $33.67(\mathrm{SD}=13.24)$ and for private schools of $33.93(\mathrm{SD}=13.11)$. 
Table 4. Test $\mathrm{t}$ for independent samples according to the ownership of educational centers

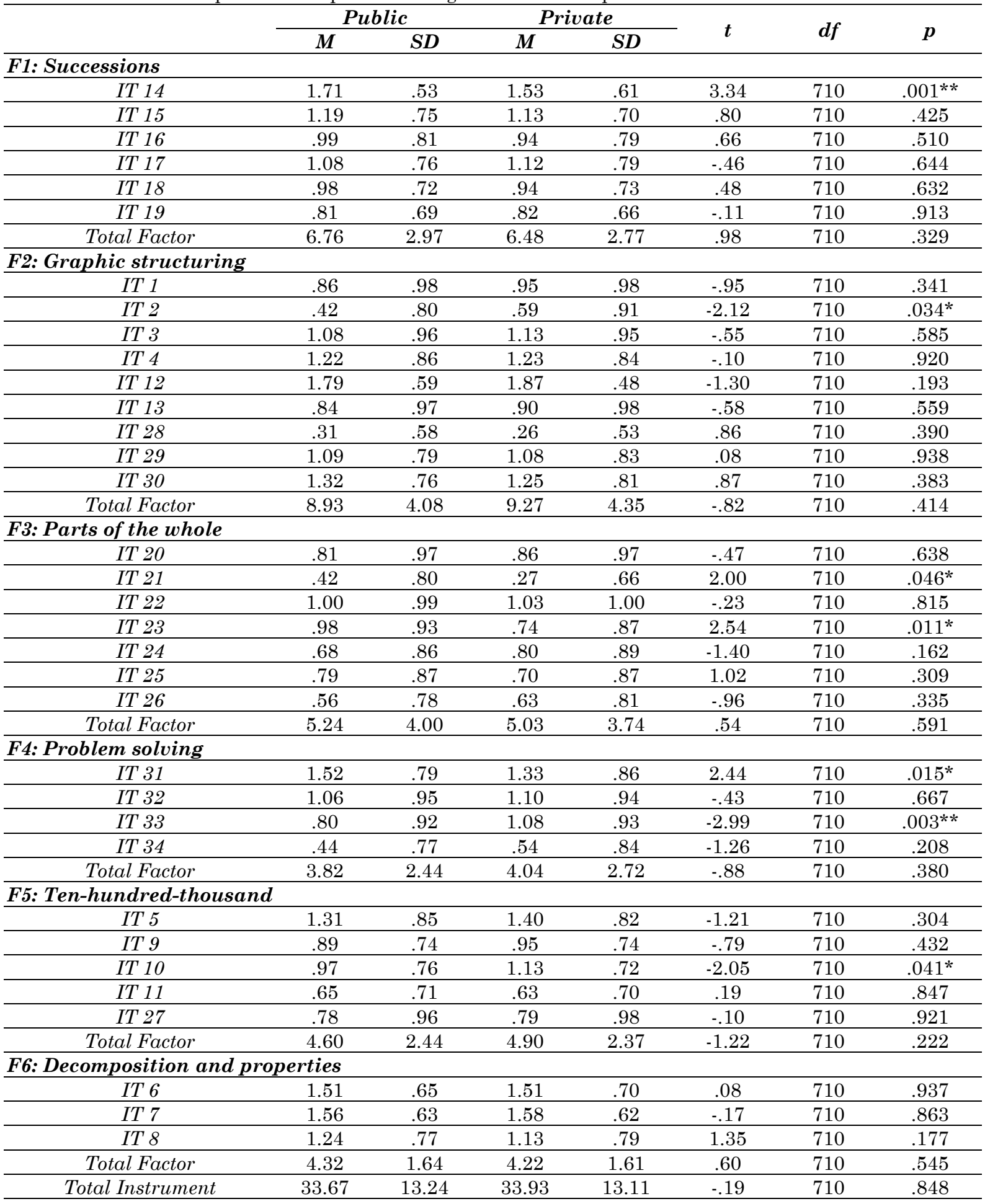

* Significant to $5 \%(\mathrm{p}<.05) * *$ Significant to $1 \%(\mathrm{p}<.01)$

Source: Own elaboration, 2019

After analyzing the results, Table 5, no statistically significant differences appeared between the two types of centers, with the mean value of the urban ones being $34.27(\mathrm{SD}=13.35)$ and that of the rural ones of 32.42 $(\mathrm{SD}=12.82)$. On the other hand, there have been statistically significant differences in some items and factors in favor of schools belonging to urban environments (items 3, 4, 10, 11, 19 and 28 and factors Graphic structuring and Ten-hundred-thousand). 
Table 5. Test $\mathrm{t}$ for independent samples according to the environment of the educational centers

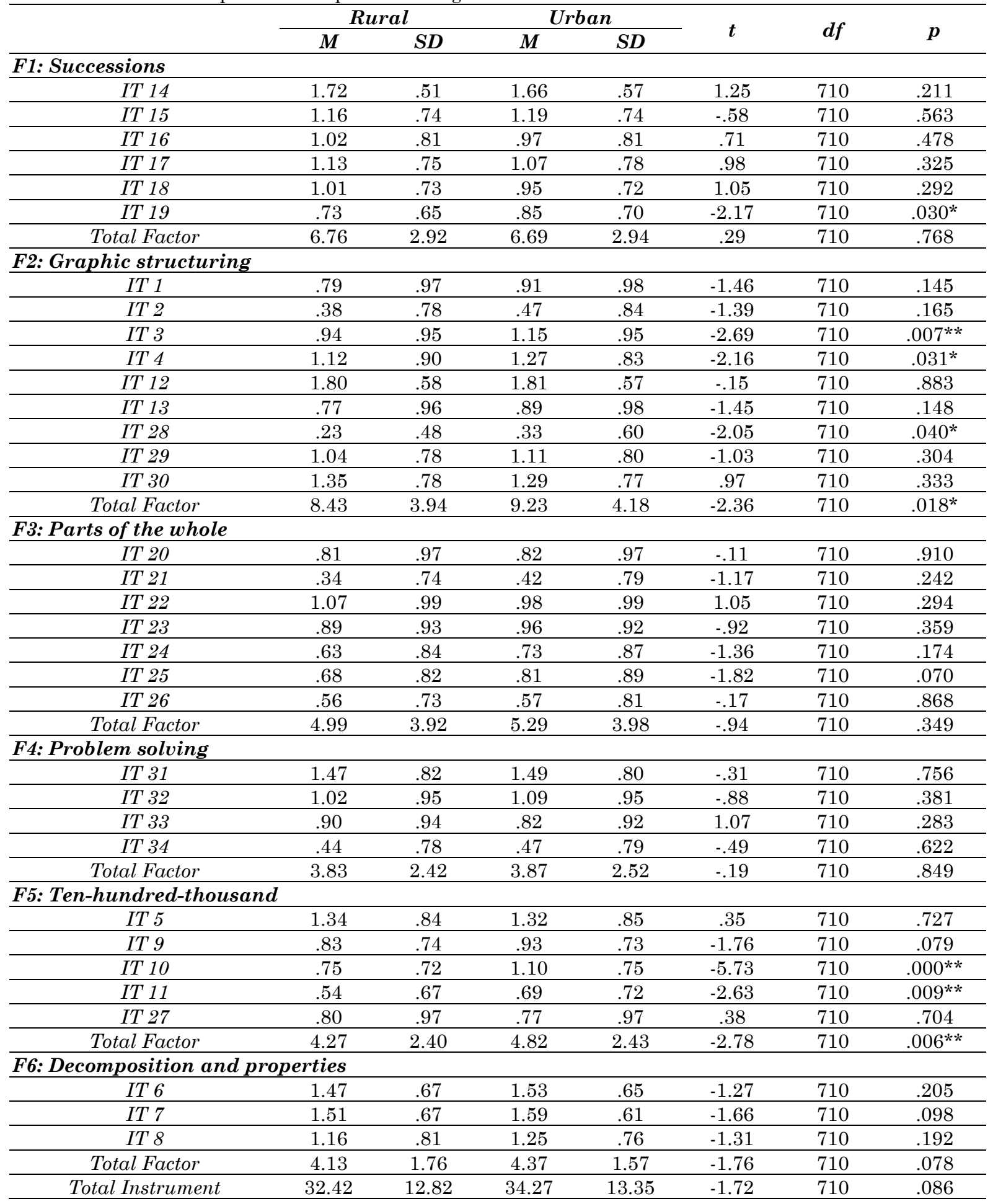

* Significant to $5 \%(\mathrm{p}<.05) * *$ Significant to $1 \%(\mathrm{p}<.01)$

Source: Own elaboration, 2019

\section{DISCUSSION OF THE RESULTS AND CONCLUSIONS}

The main purpose of the results and conclusions of the PISA Reports is to guide the education policies of the participating countries, all with a view to the generalization of reforms that favor the improvement of the 
educational achievements of the students (Mesa, Gómez, \& Cheah, 2013). These changes and innovations affect all the elements included in the educational processes, especially striking in relation to the evaluation, which entails a necessary redefinition of the connections between all the elements that constitute the school practices: curriculum, students, teaching team, families and environment.

As has been shown, the educational consequences of putting this model of competences into practice are numerous. In their integration into the classrooms, it is important to redefine the relationship between the competences and the elements of the curriculum. This linkage has a importance in the Organic Law for the Improvement of the Quality of Education (LOMCE, 2013), especially in relation to evaluation, such as the need to connect the results of external standardized evaluations with the carried out by the teachers in the classrooms for each curricular area (López, 2013).

In its generalization to the mathematical competence, main construct of this research, at present, there is a particular interest for its learning, since its functionality is basic to favor in the students a greater understanding of the world that surrounds it (OECD, 2019). The implementation of methodologies and evaluation tools for this competence will facilitate the knowledge of the level of learning manifested by the students to later be able to compare it with the norm and thus be able to verify their progress and difficulties. Olson, Martin and Mullis (2008) consider, based on international evaluations as PISA, that at the end of compulsory schooling, $30 \%$ of the students do not reach proficiency in mathematics, so there is a certain failure of the educational systems to attend educationally to the students within this competence.

In this article we have shown the results achieved in an assessment instrument that measures mathematical competence. Regarding the ownership variable, there have been few significant values between public and private centers there being differences in favor of both. The mathematical performance obtained in the BECOMA has not confirmed differences in favor of any of the types of centers according to their ownership. Other research shows that there is no incidence of school ownership over the academic performance of students (Fertig, 2003; Noell, 1982; Sander, 1996; Smith \& Naylor, 2005; Somers, McEwan, \& Willms, 2004).

In PISA 2015, the scores of private schools significantly outperformed those of the public in most of the participating countries for mathematical competence, an aspect also observed in other researches (Coleman \& Hoffer, 1987; Hanushek, 1986; Opdenakker \& Van Damme, 2006; Stevans \& Sessions, 2000; Vandernberghe $\&$ Robin, 2004). Several studies have shown that these differences in performance in favor of the private sector are due to the socioeconomic advantage and to a more favorable environment for learning in the students enrolled in these centers (Choi \& Calero, 2012, 2013; INEE, 2008, 2010b, 2013; MECD, 2016a, 2016b; Roscigno $\&$ Crowley, 2001). Beck and Shoffstall (2005) state that $70 \%$ of the variance in school results between centers according to their ownership is explained by socioeconomic factors.

In the words of the research group coordinated by Calero (2008), the contribution of this relationship between centers according to their public or private ownership is statistically zero. They defend the existence of differences derived from a compositional effect, that is, the students enrolled in private schools "come from a favorable socioeconomic environment, in these schools the educational climate is better and they have access to a smaller number of immigrants; these are the factors that ultimately explain the best results in private centers" (2008, p. 63).

Fernández (2008) affirms that access to private schooling increases in the urban environment and among social sectors with greater purchasing power, in terms of economic and cultural resources. Besides, it considers that public education is decreasing its percentage of students from families of middle and/or high social class and, nevertheless, most of the students from the most disadvantaged groups appear schooled in the public school, resulting in greater heterogeneity and support needs.

According to the environment variable, there have been few statistically significant differences between urban and rural centers. The existing ones have been in favor of urban centers. Mathematical performance has been minimally influenced by the center environment of the students. There are multiple investigations that have addressed the effect of the environment of educational centers, rural or urban, on the mathematical performance of students. Some of them (OECD, 2012, 2013; Elosua, 2013), follow the tendency indicated that, the educational centers of urban areas, obtain superior results to the rural ones, justifying this situation to greater educational, social and cultural opportunities of the first few that affect school performance and, bearing in mind, that socioeconomic status explains only a part of these differences.

One of the countries that has more research for this variable is the United States. Between your conclusions, there are studies that do not find significant differences in the academic results of students enrolled in both types of centers (Edington \& Martellaro, 1984; Monk and Haller, 1986). On the contrary, there 
are other investigations that confirm the variability of performance according to the environment of their schools (Blackwell \& McLaughlin, 1999; Kleinfeld, McDiarmid, \& Hagstrom, 1985).

Following the results of international evaluations, type PISA, they conclude for the mathematical competence and in function of the geographical area where the educational center is located, that there are differences in the performance not statistically significant in favor of the urban ones. In the specific case of Spain, it is a country with little influence in the area of location of schools in the progress of their students (INEE, 2013; MECD, 2016b). Other investigations regarding this possible effect of the variable environment on performance find statistically significant differences between centers in favor of urban centers (Gaviria \& Barrientos, 2001; McEwan, 2008) and others in which they do not appear (Santos, 2007; Wossmann, 2010).

According to Llevot and Garreta (2008), these few differences between rural and urban centers could be explained by the use in education of emerging technologies, resources that have helped to reduce the differences between one environment and another in a gradual way. In line with this, these researchers think that these environments appear closer and closer despite the very different idiosyncrasy that defines each one of them.

Other investigations justify these possible discrepancies in students' results for this variable more due to the characteristics of the students, their families and their schools that are due to the location of the center itself (Hannaway \& Talbert, 1993; Ramos, Duque, \& Nieto, 2012; Young, 1998). According to Bustos (2011) the instructional practices, the teaching and learning environments, the educational progress of the students and the management of the teaching resources are not different between rural and urban schools, although it recognizes weaknesses in the training of teachers in the rural centers (Bustos, 2006, 2008).

In this way, schools in rural areas have a greater number of families with few economic resources and lower levels of education and their centers are usually less equipped with teaching materials. This confirms that there are distinctive characteristics of rural and urban centers, distinctive notes that are hardly mentioned in the current legal frameworks (Santamaría, 2014).

It can be concluded by calling attention to the importance of reflecting on the excessive importance that is being given to standardized evaluation discourse in social and cultural development. For our part, we will continue with the generalization of research on the educational response to students according to their contextual framework and for mathematical competence, expanding the sample to other provinces and regions to obtain more significant results from our country.

\section{Disclosure statement}

No potential conflict of interest was reported by the authors.

\section{Notes on contributors}

Ramón García-Perales - University of Castilla-La Mancha (UCLM), Spain.

Ascensión Palomares-Ruiz - University of Castilla-La Mancha (UCLM), Spain.

\section{REFERENCES}

Arnaiz, P. (2012). Escuelas eficaces e inclusivas: cómo favorecer su desarrollo. Educatio Siglo XXI, 30(1), 2544.

Beck, F., \& Shoffstall, G. (2005). How do rural schools fare under a high stakes testing regime? Journal of Research in Rural Education, 20(14), 1-12.

Blackwell, D., \& Mclaughlin, D. (1999). Do Rural Youth Attain Their Educational Goals? Rural Development Perspectives, 13(3), 37-44.

Bustos, A. (2006). Los grupos multigrado de Educación Primaria en Andalucía. Granada: Grupo Editorial Universitario.

Bustos, A. (2008). Docentes de escuela rural. Análisis de su formación y sus actitudes a través de un estudio cuantitativo en Andalucía. Revista de Investigación Educativa, 26(2), 485-520.

Bustos, A. (2011). Investigación y escuela rural: ¿Irreconciliables? Profesorado, Revista de currículum y formación del profesorado, 15(2), 155-170. 
Calero, J., Quiroga, A., Escardíbul, J. O., Waisgrais, S., \& Mediavilla, M. (2008). Sociedad desigual, ¿educación desigual? Sobre las desigualdades en el sistema educativo español. Madrid: Centro de Investigación y Documentación Educativa (CIDE), Ministerio de Educación, Política Social y Deporte.

Castro, M. (2011). ¿Qué sabemos de la medida de las competencias? Características y problemas psicométricos en la evaluación de competencias. Bordón, 63(1), 109-123.

Choi, A., \& Calero, J. (2012). Rendimiento académico y titularidad de centro en España. Profesorado, Revista de currículum y formación del profesorado, 16(3), 31-57.

Choi, A., \& Calero, J. (2013). Determinantes del riesgo de fracaso escolar en España en PISA 2009 y propuestas de reforma. Revista de Educación, 362, 562-593. https://doi.org/10.4438/1988-592X-RE-2013-362-242

Cleary, T., \& Chen, P. (2009). Self-regulation, motivation and math achievement in middle school: Variations across grade level and math context. Journal of School Psychology, 47(5), 291-314. https://doi.org/10.1016/j.jsp.2009.04.002

Coleman, J., \& Hoffer, T. (1987). Public and private high schools. The impact of communities. New York: Basic Books.

Edington, E., \& Martellaro, H. (1984). Variables affecting academic achievement in New Mexico schools. Las Cruces: New Mexico Center for Rural Education.

Elosua, P. (2013). Diferencias individuales y autonómicas en el estatus socioeconómico y cultural como predictores en PISA 2009. Revista de Educación, 361, 646-664. https://doi.org/10.4438/1988-592X-RE2013-361-236

Fernández, M. (2008). Escuela pública y privada en España: La segregación rampante. Profesorado, Revista de currículum y formación del profesorado, 12(2), 1-27.

Fernández-González, N. (2015). PISA como instrumento de legitimación de la reforma de la LOMCE. Bordón, 67(1), 165-178. https://doi.org/10.13042/Bordon.2015.67111

Fertig, M. (2003). Who"s to Blame? The Determinants of German Students. Achievement in the PISA 2000 Study. IZA Discussion Paper Series, 739, 1-18.

Gaviria, A., \& Barrientos, J. (2001). Calidad de la educación y rendimiento académico en Bogotá. Coyuntura Social, 24, 111-127.

Guven, B., \& Cabakcor, B. O. (2013). Factors influencing mathematical problem-solving achievement of seventh grade Turkish students. Learning and Individual Differences, 23, 131-137. https://doi.org/10.1016/j.lindif.2012.10.003

Hannaway, J., \& Talbert, J. (1993). Bringing context into effective school research: Urban-suburban differences. Educational Administration Quarterly, 29, 164-186. https://doi.org/10.1177/ $0013161 X 93029002004$

Hanushek, E. (1986). The economics of schooling. Journal of Economic Literature, 24, 1141-1177.

Instituto Nacional de Evaluación Educativa. (2008). PISA 2003. Matemáticas. Informe español. Madrid: Ministerio de Educación, Cultura y Deporte.

Instituto Nacional de Evaluación Educativa. (2010a). Evaluación General de Diagnóstico 2009. Educación Primaria. Informe de resultados. Madrid: Ministerio de Educación, Cultura y Deporte.

Instituto Nacional de Evaluación Educativa. (2010b). PISA 2009: Informe Español. Madrid: Ministerio de Educación, Cultura y Deporte.

Instituto Nacional de Evaluación Educativa. (2012). PIRLS-TIMSS 2011: Estudio internacional de progreso en Comprensión Lectora, Matemáticas y Ciencias. Volumen I: Informe Español. Madrid: Ministerio de Educación, Cultura y Deporte.

Instituto Nacional de Evaluación Educativa. (2013). PISA 2012: Informe Español. Volumen I: Resultados y contexto. Madrid: Ministerio de Educación, Cultura y Deporte.

Instituto Nacional de Evaluación Educativa. (2016). TIMSS 2015. Estudio internacional de tendencias en Matemáticas y Ciencias. IEA. Informe español: resultados y contexto. Madrid: Ministerio de Educación, Cultura y Deporte.

Kleinfeld, J., McDiarmid, W., \& Hagstrom, D. (1985). Alaska”s small rural high schools: Are they working? Alaska: ISER Report Series No. 57, University of Alaska.

Lassibille, G., \& Navarro, M. L. (2004). Manual of economics of education. Theory and practical cases. Madrid: Pirámide. 
Llevot, N., \& Garreta, J. (2008). Escuela rural y sociedad. Lleida: Servei de Biblioteca i Documentació, Universitat de Lleida.

López, A. (2013). Alineación entre las evaluaciones externas y los estándares académicos: El Caso de la Prueba Saber de Matemáticas en Colombia. Revista Electrónica de Investigación y Evaluación Educativa, 19(2), 1-15. https://doi.org/10.7203/relieve.19.2.3024

López, M. A. (2013). Aprendizaje, competencias y TIC. Aprendizaje basado en competencias. México: Pearson. https://doi.org/10.1174/021037013808200285

Mcewan, P. (2008). Evaluating multigrade school reform in Latin America. Comparative Education, 44(4), 465-483. https://doi.org/10.1080/03050060802481504

Mesa, V., Gómez, P., \& Cheah, U. (2013). Influence of international studies of student achievement on mathematics teaching and learning. In A. J. Bishop et al. (Eds.), Third International Handbook of Mathematics Education, 861-900. Dordrecht: Kluwer. https://doi.org/10.1007/978-1-4614-4684-2_27

Meyer, H. D., \& Benavot, A. (2013). PISA, power and policy: The emergence of global education governance. Oxford: Symposium Books. https://doi.org/10.15730/books.85

Ministerio de Educación, Cultura y Deporte. (2013). Ley Orgánica 8/2013, de 9 de Diciembre, para la mejora de la calidad educativa (LOMCE)”. Boletín Oficial del Estado, 295, 97858-921. Madrid: Ministerio de Educación, Cultura y Deporte.

Ministerio de Educación, Cultura y Deporte. (2016a). PISA 2015. Informe español. Boletín de Educación, 51, $1-4$.

Ministerio de Educación, Cultura y Deporte. (2016b). PISA 2015. Programa para la Evaluación Internacional de los Alumnos. Informe español. Madrid: Secretaría General Técnica, Ministerio de Educación, Cultura y Deporte.

Monk, D., \& Haller, E. (1986). Organizational alternatives for small/rural schools: final report to the New York state legislature. New York, NY: Cornell University.

Noell, J. (1982). Public and Catholic schools: A reanalysis of public and private schools. Sociology of Education, 55, 123-132. https://doi.org/10.2307/2112292

Olson, J., Martin, M., \& Mullis, I. (2008). TIMSS 2007. Technical report. Chestnut Hill, MA: TIMSS y PIRLS International Study Center, Boston College.

Opdenakker, M. C., \& Van Damme, J. V. (2006). Differences between secondary schools: A study about school context, group composition, school practice, and school effects with special attention to public and catholic schools and types of schools. School Effectiveness and School Improvement, 17(1), 87-117. https://doi.org/10.1080/09243450500264457

Organization for Economic Cooperation and Development. (2009). Top of the class. High performers in science in PISA 2006. Paris: PISA, OECD Publishing.

Organization for Economic Cooperation and Development. (2012). Large cities are assets or ballasts for education. PISA IN FOCUS, 17, 1-4.

Organization for Economic Cooperation and Development. (2013). What makes urban schools different? PISA IN FOCUS, 28, 1-4.

Organization for Economic Cooperation and Development. (2015a). How student performance has evolved over time? PISA IN FOCUS, 47, 1-4.

Organization for Economic Cooperation and Development. (2015b). How schools have changed over the last decade? PISA IN FOCUS, 52, 1-4.

Organization for Economic Cooperation and Development. (2016). PISA 2015: Key results. Paris: PISA, OECD Publishing.

Organization for Economic Cooperation and Development. (2019). PISA 2018: Assessment and Analytical Framework. Paris: PISA, OECD Publishing. https://doi.org/10.1787/b25efab8-en

Ramos, R., Duque, J., \& Nieto, S. (2012). Un análisis de las diferencias rurales y urbanas en el rendimiento educativo de los estudiantes colombianos a partir de los microdatos de PISA. Bilbao: XXXVIII Reunión de Estudios Regionales de la Asociación Española de Ciencia Regional (AECR).

Roderer, T., \& Roebers, C. (2013). Children's Performance Estimation in Mathematics and Science Tests over a School Year: A Pilot Study. Electronic Journal of Research in Educational Psychology, 11(1), 5-24. https://doi.org/10.25115/ejrep.v11i29.1555 
Roscigno, V., \& Crowley, M. (2001). Rurality, institutional disadvantage, and achievement/attainment. Rural Sociology, 66(3), 268-293. https://doi.org/10.1111/j.1549-0831.2001.tb00067.x

Sander, W. (1996). Catholic grade schools and academic achievement. The Journal of Human Resources, 31(3), 540-548. https://doi.org/10.1007/978-1-4757-3335-8_2

Santamaría, R. (2014). The rural school in LOMCE: opportunities and threats. Supervisión, 21(33), 1-26.

Santos, M. E. (2007). Quality of education in Argentina: Determinants and distribution using the results of PISA 2000. Bienestar y política social, 3(1), 79-109.

Sicilia, G., \& Simancas, R. (2018). Educational equity in Spain: regional comparison from PISA 2015. Madrid: Fundación Ramón Areces and Fundación Europea Sociedad y Educación.

Smith, J., \& and Naylor, R. (2005). Schooling effects on subsequent university performance: evidence for the UK university population. Economics of Education Review, 24(5), 549-562. https://doi.org/10.1016/j.econedurev.2004.07.016

Somers, M. A., Mcewan, P., \& Willms, D. (2004). How effective are private schools in Latin America? Comparative Education Review, 48(1), 48-69. https://doi.org/10.2307/3542000

Stevans, L., \& Sessions, D. (2000). Private/public school choice and student performance revisited. Education Economics, 8(2), 169-184. https://doi.org/10.1080/096452900410730

Torres, J. A., \& Castillo, S. (2016). Incidence of educational support policies in the organizational structures of the centers from the perspective of teachers: A study in the province of Jaen. Educación XX1, 19(2), 205-228. https://doi.org/10.5944/educxx1.16462

Vandernberghe, V., \& Robin, S. (2004). Evaluating the effectiveness of private education across countries: A comparison of methods. Labour Economics, 11(4), 487-506. https://doi.org/10.1016/s09275371(04)00046-6

Wossmann, L. (2010). Families, schools and primary-school learning: evidence for Argentina and Colombia in an international perspective. Applied Economics, 42(21), 2645-2665. https://doi.org/10.1080/00036840801964617

Young, D. J. (1998). Rural and urban differences in student achievement in science and mathematics: A multilevel analysis. School effectiveness and school improvement, 9(4), 386-418. https://doi.org/10.1080/0924345980090403 